\title{
Оценка Арабской весны в Ливии и Сирии: сводка заявлений ключевых действующих лиц
}

\author{
Чарльз Симпсон *
}

\section{Введение}

Ситуация в Сирии в феврале 2012 и в Ливии в 2011 дала два самых свежих учебных примера для оценки широкого разнообразия международных тем, включая будущую роль НАТО в глобальной безопасности, концепции «Ответственности Защищать» (О3) как руководящей нормы, мировую роль Лиги Арабских Государств (ЛАГ) после Арабской весны, и роль новых факторов в Совете безопасности Объединенных Наций (СБООН). Ввиду того, что Ливия 2011 и Сирия 2012 вошли в круг многих академических и профессиональных исследований, появилась необходимость компиляции разных линий политики, резолюций, действий и заявлений, соответствующих ключевым действующим лицам (политическим авторам) в обоих сценариях. Приведенная ниже таблица является попыткой представить такую компиляцию в кратком и четко структурированном формате.

\footnotetext{
Чарльз Симпсон работает стажантом-исследователем в Женевском Центре Политики Безопасности. Он изучает «Международные отношения» и «Ближневосточные исследования» в Северо-Восточном университете Бостона, штат Масачузетс. Так же учился в Школе международной подготовки в Аммане, Иордания, и университете Догюш в Стамбуле, Турция.
} 


\begin{tabular}{|c|c|}
\hline Позиция по Ливии & ция по Сирии \\
\hline \multicolumn{2}{|l|}{ Группа 1 - Международные организации } \\
\hline p-Совет Безопас & ти Объединенных Наций (СБООН) \\
\hline 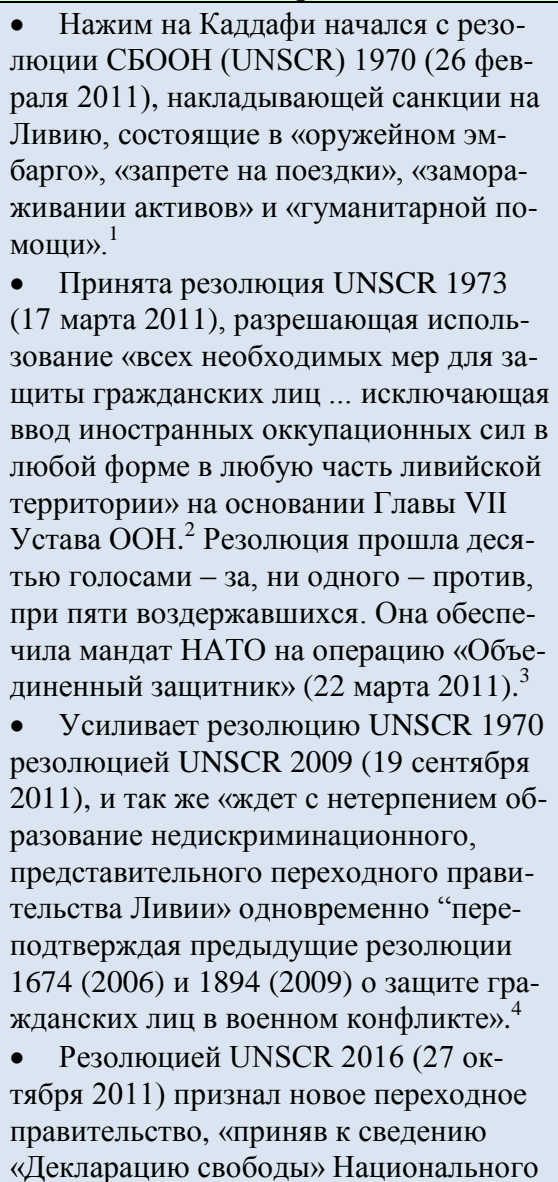 & $\begin{array}{l}\text { • } \quad \text { Был представлен проект резолюции } \\
\text { СБООН (4 октября 2011), осуждающий «тяже- } \\
\text { лые и систематические нарушения прав чело- } \\
\text { века» в Сирии, в который была включена } \\
\text { «ссылка на Статью } 41 \text { Устава ООН», позво- } \\
\text { ляющая применение санкций. Никакие кон- } \\
\text { кретные санкции, однако, не были упомя- } \\
\text { нуты. } \\
\text { • } \quad \text { Генеральная ассамблея ООН приняла Резо- } \\
\text { люцию } 2443 \text { (19 декабря 2011), «строго осуж- } \\
\text { дающую» правительство Ассада. } \\
\text { • Был представлен второй проект резолюции } \\
\text { СБООН (4 февраля 2012), «выражающий серь- } \\
\text { езную озабоченность ухудшением ситуации в } \\
\text { Сирии», «отмечающий заявленную готовность } \\
\text { сирийских властей к реформам», «осуждающий } \\
\text { продолжающиеся широкомасштабные и значи- } \\
\text { тельные нарушения прав человека и фундамен- } \\
\text { тальных свобод со стороны сирийских вла- } \\
\text { стей», «требующий, чтобы сирийское прави- } \\
\text { тельство незамедлительно положило конец } \\
\text { всем нарушениям прав человека» и «требую- } \\
\text { щий, чтобы сирийское правительство ... защи- } \\
\text { тило свое население». Однако, эта резолюция } \\
\text { не упоминала столб два и три ОЗ, и не предла- } \\
\text { гала военную интервенцию. На нее наложили } \\
\text { вето Россия и Китай, тогда как все остальные } \\
\text { члены СБ проголосовали «за». }\end{array}$ \\
\hline
\end{tabular}

1 UN Security Council Resolution 1970, 26 February 2011; доступна на http://daccess-ddsny.un.org/doc/UNDOC/GEN/N11/245/58/PDF/N1124558.pdf?OpenElement.

2 UN Security Council Resolution 1973, 17 March 2011; доступна на http://daccess-ddsny.un.org/doc/UNDOC/GEN/N11/268/39/PDF/N1126839.pdf?OpenElement.

3 Operation Unified Protector Final Mission Statistics, Fact Sheet, North Atlantic Treaty Organization Press \& Media Section Media Operations Centre (Brussels, 2011); доступно на http://www.nato.int/nato_static/assets/pdf/pdf_2011_11/20111108_111107-factsheet_up_facts figures_en.pdf.

4 UN Security Council Resolution 2009, 19 September 2011; доступно на http://daccess-ddsny.un.org/doc/UNDOC/GEN/N11/502/44/PDF/N1150244.pdf?OpenElement. 


\begin{tabular}{|c|c|}
\hline $\begin{array}{l}\text { Переходного Правительства от } 23 \text { ок- } \\
\text { тября } 2011 \text { \. }^{5} \\
\text { • } \quad \text { Резолюцией UNSCR } 2017 \text { (31 ок- } \\
\text { тября 2011) призвал к стабилизации и } \\
\text { разоружению в Ливии, «признавая } \\
\text { срочную необходимость дополнитель- } \\
\text { ных усилий на национальном, регио- } \\
\text { нальном и международном уровне для } \\
\text { предотвращения распространения лю- } \\
\text { бых видов оружия». } \\
\text { • } \quad \text { «Приветствовал образование пере- } \\
\text { ходного правительства в Ливии» в резо- } \\
\text { люции UNSCR } 2022 \text { (2 декабря 2011), } \\
\text { таким образом подтверждая законность } \\
\text { Национального Переходного Совета } \\
\text { (НПС). }\end{array}$ & \\
\hline \multicolumn{2}{|c|}{ Политический актор - Лига Арабских Государств (ЛАГ) } \\
\hline $\begin{array}{l}\text { • } \quad \text { Отстраняет ливийскую делегацию от } \\
\text { участия в Совете Лиги (22 февраля } \\
2011){ }^{9} \\
\text { • } \quad \text { Взывает к СБООН с целью «принять } \\
\text { необходимые меры для незамедлитель- } \\
\text { ного введения запретной для полетов } \\
\text { ливийской авиации зоны», чтобы «обес- } \\
\text { печить ливийскому народу ... необходи- } \\
\text { мую защиту» в ответ на «насилие и тя- } \\
\text { желые преступления, совершаемые ли- } \\
\text { вийскими властями», которые потеряли } \\
\text { свою легитимность. Резолюция ЛАГ } \\
\text { (LASR) } 7360 \text { (12 марта 2011). }{ }^{10} \\
\text { • } \quad \text { Признает НПС законным правитель- } \\
\text { ством Ливии, подтверждая представи- }\end{array}$ & $\begin{array}{l}\text { • } \quad \text { ЛАГ отстранила Сирию от участия в } \\
\text { заседаниях Совета Лиги из-за атак правитель- } \\
\text { ства Ассада против гражданского населения } \\
\text { (16 ноября 2011). }{ }^{12} \\
\text { • } \quad \text { Приняла резолюцию LASR } 7441, \text { начав } \\
\text { миссию наблюдателей в Сирии ( } 24 \text { ноября } \\
2011){ }^{13} \text { Миссия наблюдателей была приоста- } \\
\text { новлена } 29 \text { января } 2012 \text { из-за неприемлемого } \\
\text { уровня насилия в стране. }{ }^{14} \\
\text { • Приняла резолюцию LASR } 7442 \text { (27 ноября } \\
\text { 2011), наложив санкции на Ливию, чтобы «за- } \\
\text { претить поездки высших официальных лиц } \\
\text { Сирии», остановить «транзакции с Централь- } \\
\text { ным банком Сирии», прекратить «правительст- } \\
\text { венные торговые транзакции с сирийским го- }\end{array}$ \\
\hline
\end{tabular}

8 UN Security Council Draft Resolution, 4 February 2012 (minutes of the $6711^{\text {th }}$ meeting of the UNSC); доступно на http://daccess-dds-ny.un.org/doc/UNDOC/PRO/N12/223/56/PDF/N1222 356.pdf?OpenElement.

5 UN Security Council Resolution 2016, 27 October 2011; доступно на http://daccess-ddsny.un.org/doc/UNDOC/GEN/N11/567/10/PDF/N1156710.pdf?OpenElement.

6 UN Security Council Resolution 2017, 31 October 2011; доступно на http://daccess-ddsny.un.org/doc/UNDOC/GEN/N11/573/ 33/PDF/N1157333.pdf?OpenElement.

7 UN Security Council Resolution 2022, 2 December 2011; доступно на http://daccess-ddsny.un.org/doc/UNDOC/GEN/N11/620/28/PDF/N1162028.pdf?OpenElement.

9 Dominic Evans, "Syrian Forces Break up Hama Protest Marking Killings," Reuters (3 February 2012); доступно на http://af.reuters.com/article/worldNews/idAFL6E8C52E22012020?sp=true.

10 League of Arab States Resolution 7360, "The outcome of the Council of the League of Arab States meeting at the ministerial level," Cairo, 12 March 2011; доступно на http://responsibilitytoprotect.org/Arab League Ministerial level statement 12 march 2011 english (1).pdf. 


\begin{tabular}{|c|c|}
\hline $\begin{array}{l}\text { тельство НПС в Совете ЛАГ ( } 27 \text { августа } \\
\text { 2011). }{ }^{11}\end{array}$ & $\begin{array}{l}\text { сударством» и заморозить «финансовые активы } \\
\text { сирийского правительства». } \\
\text { • } \quad \text { Призвала к «формированию правительства } \\
\text { национального единства» для того, чтобы } \\
\text { «международное сообщество оказало под- } \\
\text { держку правительству национального един- } \\
\text { ства», и чтобы режим Ассада «отказался от лю- } \\
\text { бого использования военной силы», резолюции } \\
\text { LASR } 7444 \text { и } 7445 \text { (22 января 2012). } \\
\text { • }{ }^{16} \text { Приняла резолюцию LASR } 7446 \text { (12 фев- } \\
\text { раля 2012), призывая начать совместную опе- } \\
\text { рацию ОOН-ЛАГ по поддержанию мира в Си- } \\
\text { рии, на основании «Обязанности защищать» } \\
\text { гражданские лица. }{ }^{17} \text { Правительство Сирии от- } \\
\text { вергло миссию, предложенную для поддержа- } \\
\text { ния мира. }{ }^{18}\end{array}$ \\
\hline
\end{tabular}

12 Sheikh Hamad bin Jassem bin Jabr al-Thani, League of Arab States Official Press Release Statement, Cairo (13 November 2011); доступно на www.chinadaily.com.cn/world/2011-11/13/ content_14085036.htm.

13 Muhammad Ahmad Mustafa al-Dabi, "Report of the Head of the League of Arab States Observer Mission to Syria for the period from 24 December 2011 to 18 January 2012," Cairo, 27 January 2012; доступно на www.innercitypress.com/LASomSyria.pdf.

14 "Amid Violence, Arab League Suspends Observer Mission in Syria," CNN (28 January 2012); доступно на http://edition.cnn.com/2012/01/28/world/meast/syria-unrest/index.html?hpt=hp_t3.

11 League of Arab States Resolution 7370, “The Situation in Libya," Cairo, 27 August 2011; доступно на http://arableagueonline.org/wps/wcm/connect/1b53548048e9ef94b16bfd7abaae88c3/ $\% \mathrm{D} 9 \% 82 \% \mathrm{D} 8 \% \mathrm{~B} 1 \% \mathrm{D} 8 \% \mathrm{~A} 7 \% \mathrm{D} 8 \% \mathrm{~B} 1+7370$. pdf?MOD=AJPERES.

15 League of Arab States Resolution 7442, "Following the Developments of the Situation in Syria," Cairo, 27 November 2011; доступно на http://www.openbriefing.org/regionaldesks/ middleeast/resolution7442.

16 League of Arab States Resolution 7444, "On the developments of the situation in Syria and the elements of the Arab Roadmap to solve the Syrian Crisis," Cairo, 22 January 2012; доступно на www.arableagueonline.org/wps/wcm/connect/76a9db8049e4238ba551bd526698d42c/res+74 44.pdf?MOD=AJPERES.

17 League of Arab States Resolution 7446, "Follow-up Developments on the Worsening Situation in Syria," Cairo, 12 February 2012; доступно на http://arableagueonline.org/wps/wcm/ connect/dbd065804a2433d984769c526698d42c/7446.pdf?MOD=AJPERES.

18 H. Zein, "Syria Rejects Decisions of AL Ministerial Meeting as Flagrant Interference in Syria's Affairs \& Encroachment on its National Sovereignty," Sana Syria News Agency (14 February 2012); доступно на www.sana.sy/eng/21/2012/02/14/400175.htm. 


\begin{tabular}{|c|c|}
\hline \multicolumn{2}{|l|}{ Политический актор - Европейский Союз (ЕС) } \\
\hline 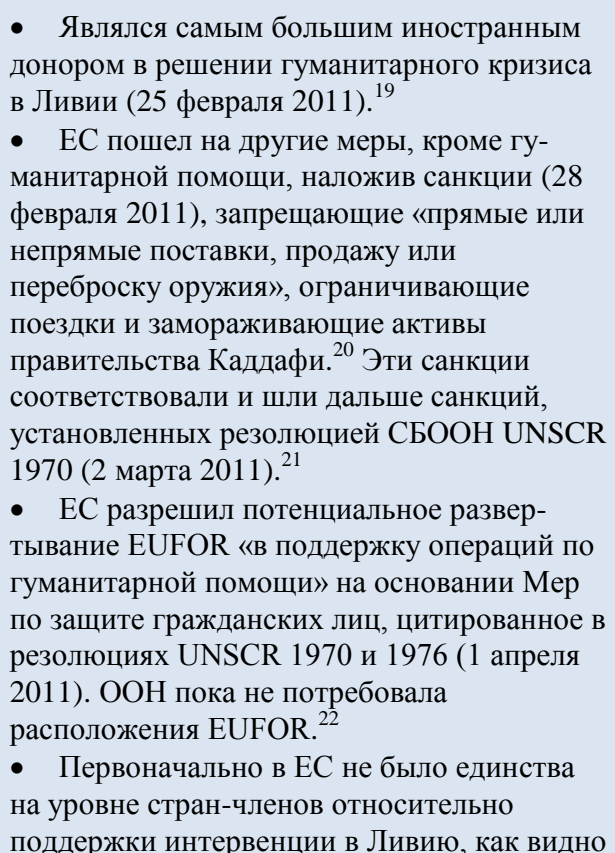 & $\begin{array}{l}\text { • Наложил на Сирию эмбарго, } \\
\text { охватывающее «оборудование, которое } \\
\text { можно использовать для внутренних } \\
\text { репрессий», «запрет на импорт сырой } \\
\text { нефти и нефтяных продуктов», «ограни- } \\
\text { чения на визы для определенных лиц» и } \\
\text { «замораживание фондов и экономических } \\
\text { ресурсов определенных лиц, организаций и } \\
\text { госструктур», инициированное в } 2011 \text { и } \\
\text { подтвержденное в } 2012 .^{23} \\
\text { • Эти меры входят в противоречие с } \\
\text { более ранними усилиями расширить } \\
\text { торговые отношения с Сирией, как } \\
\text { планировалось в Стратегическом } \\
\text { документе ЕС } 2007-2013 \text { и в связи с } \\
\text { фактом, что ЕС является основным } \\
\text { торговым партнером Сирии. }{ }^{24} \\
\text { • } \quad \text { Недавнее развитие событий в Сирии } \\
\text { отложило реализацию экономических и } \\
\text { политических договоренностей о } \\
\text { сотрудничестве между ЕС и Сирией. }{ }^{25} \\
\text { Примерно до } 2008 \text { года отношения ЕС- } \\
\text { Сирия были позитивными и демон- }\end{array}$ \\
\hline
\end{tabular}

19 European Union Press Release, "Crisis in Libya: European Commission Allocates €3 Million to Address Humanitarian Needs," Brussels, 25 February 2011; доступно на http://europa.eu/ $\mathrm{rapid} /$ pressReleasesAction.do?reference=IP/11/228.

20 European Union, Council Decision 2011/137/CFSP concerning restrictive measures in view of the situation in Libya, Brussels, 28 February 2011; доступно на http://eur-lex.europa.eu/ LexUriServ/LexUriServ.do?uri=OJ:L:2011:058:0053:0062:EN:PDF.

21 European Union, Council Regulation No.204/2011, Brussels, 2 March 2011; доступно на http://eur-lex.europa.eu.

22 European Union, Council Decision 2011/210/CFSP, Brussels, 1 April 2011; доступно на http://eur-lex.europa.eu/LexUriServ/LexUriServ. do?uri=OJ:L:2011:089:0017:0020:en:PDF.

23 European Union Restrictive Measures (Sanctions) in Force (Brussels, 2012); доступно на www.google.ch/url?sa=t\&rct=j\&q=european commission - restrictive measures restrictive measures in force \&source=web\&cd=1\&ved=0CCIQFjAA\&url=http $\% 3 \mathrm{~A} \% 2 \mathrm{~F} \% 2 \mathrm{Feeas}$.europa. eu\%2Fcfsp\%2Fsanctions\%2Fmeasures.htm\&ei=5fg4T8LoOKrf4QT517WhCw\&usg.

24 European Commission, European Neighborhood and Partnership Instrument: Syrian Arab Republic: Strategy Paper 2007-2013 \& National Indicative Programme 2007-2010 (Brussels: European Commission, 2007); доступно на http://ec.europa.eu/world/enp/pdf/country/enpi_ csp_nip_syria_en.pdf.

25 Bilateral Agreement, Council of the European Union, "Cooperation Agreement between the European Economic Community and the Syrian Arab Republic," L269 (Brussels: Official Journal of the European Communities, 1977); доступно на http://ec.europa.eu/world/agreements/ prepareCreateTreatiesWorkspace/treatiesGeneralData.do?step $=0 \&$ redirect=true $\&$ treatyId $=255$. 


\begin{tabular}{|c|c|}
\hline $\begin{array}{l}\text { из факта, что Германия воздержалась при } \\
\text { голосовании по принятию резолюции } \\
\text { UNSCR } 1970 \text { (26 февраля 2011), }{ }^{1} \text { а также из } \\
\text { одностороннего признания Францией } \\
\text { законности ПНС (10 марта 2011), }{ }^{38} \text { но } \\
\text { минимальная роль ЕС в конфлике } \\
\text { предотвратила политические трения по этим } \\
\text { спорным вопросам. }\end{array}$ & $\begin{array}{l}\text { стрировали признаки расширяющегося } \\
\text { участия в Евро-Средиземноморском } \\
\text { партнерстве. }{ }^{26} \text { Наоборот, нынешние } \\
\text { декларации ЕС поддерживают призывы } \\
\text { ЛАГ и ООН «усилить международное } \\
\text { давление на сирийский режим» и при- } \\
\text { ветствуют любые «предложения } \\
\text { остановить насилие и облегчить страдания } \\
\text { сирийского населения». }{ }^{27}\end{array}$ \\
\hline \multicolumn{2}{|l|}{ Политический актор - Африканский Союз (АC) } \\
\hline $\begin{array}{l}\text { - AC поддержал санкции по отношению к } \\
\text { Ливии, наложенные резолюцией СБООН } \\
\text { UNSCR } 1970 \text { (26 февраля 2011) и поддержал } \\
\text { O3 миссию в UNSCR 1973, призывающую к } \\
\text { «защите гражданских лиц и прекращению } \\
\text { вооруженных действий» на «аd hос» встрече } \\
\text { по ситуации в Ливии (25 марта 2011). }{ }^{28}\end{array}$ & $\begin{array}{l}\text { - } \quad \text { Официальные заявления гласят, что } \\
\text { описания СМИ насилия в стране доходят } \\
\text { до «заблуждающей кампании, проводимой } \\
\text { некоторыми СМИ с целью очернить } \\
\text { имидж Сирии» и призывают к солидарно- } \\
\text { сти между арабским и африканскими наро- } \\
\text { дами». Отряды оппозиции определяются } \\
\text { как террористы (22 октября 2011). }{ }^{29}\end{array}$ \\
\hline \multicolumn{2}{|c|}{ Политический актор - Совет по сотрудничеству стран Персидского залива (СССПЗ) } \\
\hline $\begin{array}{l}\text { - Сделал заявление, практически повто- } \\
\text { ряющее и поддерживающее резолюцию } \\
\text { СБООН UNSCR 1970. СССПЗ «осудил серь- } \\
\text { езные нарушения прав человека и междуна- } \\
\text { родного гуманитарного права, совершаемые } \\
\text { ливийскими властями», «выразил свою под- } \\
\text { держку резолюции СБООН No. 1970» и при- } \\
\text { звал «Совет Безопасности ОOН наложить } \\
\text { воздушное эмбарго, чтобы защитить граж- } \\
\text { дан Ливии» (8 марта 2011). }{ }^{30}\end{array}$ & $\begin{array}{l}\text { • СССПЗ поддержал миссию наблюдате- } \\
\text { лей ЛАГ, предоставив сорок два человека } \\
\text { из первоначального состава миссии (ото- } \\
\text { звал двоих) и двадцать одно транспортное } \\
\text { средство. }\end{array}$ \\
\hline
\end{tabular}

${ }^{26}$ Council of the European Union, Barcelona Process: Union for the Mediterranean Ministerial Conference (Marseille: Consilium Press Office, 2008); доступно на www.consilium.europa.eu/ ueDocs/cms_Data/docs/pressData/en/misc/103733.pdf.

27 European Union, Statement by High Representative Catherine Ashton on the decisions by the League of Arab States on Syria, Brussels, 13 February 2012; доступно на www.consilium.europa.eu/uedocs/cms_data/docs/pressdata/EN/foraff/127953.pdf.

28 African Union Communique, "Meeting of the African Union High-Level Ad Hoc Committee on Libya," Addis Ababa, 19 March 2011; доступно на http://au.int/en/dp/ps/sites/default/files/ Communique_en_19_March_2011_PSD_Meeting_au_High_Level_ad_hoc_committee_Libya_ Nouakchott_Islamic_Republic_Mauritania.pdf .

29 African Union Press Release, "Chairperson Ping Receives the Deputy Minister of Foreign Affairs," Addis Ababa, 22 October 2011; доступно на www.au.int/ar/dp/cpauc/sites/default/ files/Chairperson Ping receives the Deputy Foreign Minister of Syria.pdf.

30 Joint Statement issued by the Joint Ministerial Meeting of the Strategic Dialogue between the Countries of the Cooperation Council for the Arab Gulf States and Australia (Riyadh: Gulf Cooperation Council Secretariat, 8 March 2011); доступно на http://www.gcc-sg.org/index c23e.html?action=News\&Sub=ShowOne \&ID=1919. 


\section{Группа 2 - пять постоянных членов СБООН (СБООН П5)}

\section{Политический актор - Соединенные Штаты}

- Сенат США принял необвязывающую резолюцию S.RES.85 (1 марта 2011), «строго осуждающую значительные и систематические нарушения прав человека в Ливии» и «настоятельно призывающую Совет безопасности $\mathrm{OOH}$ предпринять необходимые дальнейшие действия для защиты граждан Ливии от нападений». Это был первый официальный документ, предлагающий иностранное вмешательство. ${ }^{31}$

- Голосовал в поддержку резолюции UNSCR 1973 (17 марта 2011). ${ }^{32}$

- Начал установление запретной для полетов зоны над Ливией в рамках операции «Заря Одиссея» совместно с Объединенным королевством и Францией (19 марта 2011) ${ }^{33}$ прежде, чем передать контроль операции НАТО «Объединенный защитник» (22 марта 2011). ${ }^{34}$
- США начали применять санкции к членам семейства Ассада в апреле 2011. ${ }^{35}$

- США голосовали в поддержку первого проекта резолюции СБООН, осуждающего правительство Сирии (4 октября 2011). ${ }^{43}$

- США голосовали в поддержку второго проекта резолюции СБООН, осуждающего правительство Сирии (4 октября 2011).

\section{Политический актор - Объединенное Королевство}

- Проголосовали в поддержку UNSCR 1973 (17 марта 2011). ${ }^{33}$

- Начали установление запретной для полетов зоны над Ливией в рамках операции «Эллами» совместно с Францией и США, прежде, чем передать контроль операции НАТО «Объединенный защитник (22 марта 2011) после того, как Парламент Объединенного Королевства одобрил использование военных средств
- Объединенное Королевство оказывало давление при принятии санкций, сосредоточившись, однако, только на принятии резолюции СБООН. ${ }^{37}$

- Объединенное королевство проголосовало в поддержку первого проекта резолюции СБООН, осуждающего сирийское правительство (4 октября 2011). ${ }^{43}$

- Объединенное королевство проголосовало

31 The White House, Executive Order 13572 (29 April 2011), (Washington, D.C.: Federal Register 76:85, 3 Мау 2011); доступно на www.treasury.gov/resource-center/sanctions/Programs/ Documents/13572.pdf .

32 United Nations Security Council Resolution, Minutes of the $6498^{\text {th }}$ Meeting of the Security Council, 2011; доступно на http://daccess-dds-ny.un.org/doc/UNDOC/PRO/N11/267/18/PDF/ N1126718.pdf?OpenElement.

33 Operation Odyssey Dawn (Libya): Background Issues for Congress, CRS Report for Congress (Washington, D.C.: Congressional Research Service, 2011); доступно на www.fas.org/ sgp/crs/natsec/R41725.pdf.

34 Operation Unified Protector Final Mission Statistics.

35 The White House, Executive Order 13582 (17 August 2011), (Washington, D.C.: Federal Register 76:162, 22 August 2011); доступно на www.treasury.gov/resource-center/sanctions/ Programs/Documents/syria_eo_08182011.pdf. 


\begin{tabular}{|c|c|}
\hline 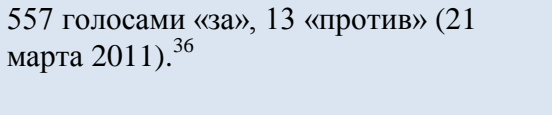 & $\begin{array}{l}\text { в поддержку второго проекта резолюции } \\
\text { СБООН, осуждающего сирийское правитель- } \\
\text { ство (4 февраля 2012). }\end{array}$ \\
\hline \multicolumn{2}{|l|}{ Политический актор - Франция } \\
\hline $\begin{array}{l}\text { • } \quad \text { Стала первым государством, при- } \\
\text { знавшим ПНС как законное правитель- } \\
\text { ство Ливии (10 марта 2011). }{ }^{38} \\
\text { • } \quad \text { Начала установление запретной для } \\
\text { полетов зоны над Ливией в рамках опе- } \\
\text { рации «Харматах» совместно с Объеди- } \\
\text { ненным Королевством и США, прежде, } \\
\text { чем передать контроль операции НАТО } \\
\text { «Объединенный защитник» (22 марта } \\
2011){ }^{39} \\
\text { • } \quad \text { Проголосовала в поддержку резолю- } \\
\text { ции UNSCR } 1973 \text { (17 марта 2011). }\end{array}$ & $\begin{array}{l}\text { • } \quad \text { Франция проголосовала в поддержку пер- } \\
\text { вого проекта резолюции, осуждающего сирий- } \\
\text { ское правительство (4 октября 2011). }{ }^{43} \\
\text { - } \quad \text { Россия и Китай наложили вето на послед- } \\
\text { нюю попытку Франции провести проект резо- } \\
\text { люции СБООН (4 февраля 2012).9 }\end{array}$ \\
\hline \multicolumn{2}{|l|}{ Политический актор - Россия } \\
\hline $\begin{array}{l}\text { • } \text { Россия воздержалась при голосова- } \\
\text { нии при принятии резолюции UNSCR } \\
1973 \text { (17 марта 2011), }{ }^{33} \text { и позднее воз- } \\
\text { ражала против операции «Объединен- } \\
\text { ный защитник» как проводимой на ос- } \\
\text { нове неправомерного использования } \\
\text { «размытых» формулировок в тексте до- } \\
\text { кумента. Россия критиковала НАТО за } \\
\text { то, что выходит за рамки ОЗ с целью } \\
\text { добиться смены режима. }\end{array}$ & $\begin{array}{l}\text { • } \quad \text { Россия наложила вето на первый проект } \\
\text { резолюции СБООН по Сирии (4 октября } \\
2011), \text { цитируя как основание «уважение к } \\
\text { национальному суверенитету ... Сирии». } \\
\text { • } \quad \text { Россия наложила вето на последний проект } \\
\text { резолюции СБООН по Сирии, обвиняя «меж- } \\
\text { дународных членов международного сообще- } \\
\text { ства» (т.е. США, Объединенное Королевство и } \\
\text { Францию) в дестабилизации ситуации «призы- } \\
\text { вами о смене режима, подталкиванием оппози- } \\
\text { ции к захвату власти, потакательством прово- } \\
\text { кациям и поощрением вооруженной борьбы», } \\
\text { и в то же время заявила, что «кровопролитие и } \\
\text { насилие в Сирии должны быть немедленно } \\
\text { прекращены». } \\
\text { • } \quad \text { Россия сделала предложение о проведении } \\
\text { неофициальных многосторонних переговоров }\end{array}$ \\
\hline
\end{tabular}

37 "Syria Unrest: UK, France and Italy Press for Sanctions," BBC World News (26 April 2011); доступно на www.bbc.co.uk/news/world-middle-east-13197277.

36 Claire Taylor, "In Brief: Parliamentary Approval for Deploying the Armed Forces," House of Commons Standard Note SN/IA/5908 (London: House of Commons Library, 7 April 2011); доступно на www.parliament.uk/briefing-papers/SN05908.pdf.

38 "Libya: France Recognises Rebels as Government," BBC News Europe (10 March 2011); доступно на www.bbc.co.uk/news/world-africa-12699183.

39 Official Statement, French Ministry of Defense, "Libye: point de situation opération Harmattan $n^{\circ} 1, "$ (25 March 2011); доступно на www.defense.gouv.fr/operations/autres-operations/ operation-harmattan-libye/actualites/libye-point-de-situation-operation-harmattan-n-1.

40 Evans, "Syrian Forces Break up Hama Protest Marking Killings." 


\begin{tabular}{|c|c|}
\hline & $\begin{array}{l}\text { без предварительных условий в Москве, } \\
\text { вместо проведения их в ООН. }{ }^{41}\end{array}$ \\
\hline \multicolumn{2}{|l|}{ Политический актор - Китай } \\
\hline $\begin{array}{l}\text { • Китайская Народная Республика } \\
\text { (КНР) пыталась сбалансировать не-ин- } \\
\text { тервенционизм поддержкой миссиям } \\
\text { Арабской Лиги в защиту мирных жите- } \\
\text { лей, воздержавшись при голосовании } \\
\text { при принятии резолюции СБООН } \\
\text { UNSCR } 1973 \text { (17 марта 2011). }{ }^{33}\end{array}$ & $\begin{array}{l}\text { - } \text { КНР наложила вето на первый проект резо- } \\
\text { люции по Сирии (4 октября 2011), заявив, что } \\
\text { ее делегация «сильно озабочена развитием со- } \\
\text { бытий в Сирии», но «считает, что в нынешней } \\
\text { ситуации санкции или угроза применения } \\
\text { санкций не помогут разрешению сирийской } \\
\text { проблемы, а наоборот, приведут к дальней- } \\
\text { шему усугублению ситуации». } \\
\text { • } \quad \text { КНР наложила вето на последний проект } \\
\text { резолюции СБООН вместе с Россией (4 фев- } \\
\text { раля 2012), цитируя как основание уважение к } \\
\text { «суверенитету, независимости и территориаль- } \\
\text { ной целостности Сирии». }\end{array}$ \\
\hline \multicolumn{2}{|c|}{ Группа 3 - другие влиятельные непостоянные члены СБООН } \\
\hline \multicolumn{2}{|l|}{ Политический актор - Индия } \\
\hline $\begin{array}{l}\text { • Воздержалась при голосовании резо- } \\
\text { люции UNSCR } 1973 \text { (17 марта 2011), } \\
\text { озвучивая озабоченность, что интервен- } \\
\text { ция увеличит количество жертв среди } \\
\text { гражданского населения и направлена в } \\
\text { большей степени к смене режима, чем } \\
\text { на O3. }\end{array}$ & $\begin{array}{l}\text { • } \quad \text { Воздержалась при голосовании первого } \\
\text { проекта резолюции СБООН (4 октября 2011), } \\
\text { заявляя, что «Индия остается озабоченной раз- } \\
\text { вивающимися событиями в Сирии», но «ввиду } \\
\text { сложности практической ситуации в Сирии мы } \\
\text { считаем, что единственный путь вперед - это ... } \\
\text { включение Сирии в совместный конструктив- } \\
\text { ный диалог и сотрудничество». } \\
\text { • } \quad \text { Проголосовала в поддержку проекта резо- } \\
\text { люции СБООН (4 февраля 2012), заявляя: «Мы } \\
\text { строго осуждаем любое насилие, независимо } \\
\text { кем совершаемое». }\end{array}$ \\
\hline \multicolumn{2}{|l|}{ Политический актор - Бразилия } \\
\hline $\begin{array}{l}\text { - Воздержалась при голосовании резо- } \\
\text { люции UNSCR } 1973 \text { (17 марта 2011), } \\
\text { выражая озабоченность, что } \\
\text { интервенция увеличит количество жертв } \\
\text { среди гражданского населения и } \\
\text { направлена в большей степени к смене } \\
\text { режима, чем на O3. }\end{array}$ & $\begin{array}{l}\text { • } \quad \text { Воздержалась при голосовании проекта ре- } \\
\text { золюции СБООН (4 октября 2011), поощряя } \\
\text { «содержательный и равноправный националь- } \\
\text { ный диалог» и использование нажима мягкой } \\
\text { силы «созданием расследующей комиссии при } \\
\text { Совете по Правам Человека», вместо примене- } \\
\text { ния санкций. } \\
\text { • } \quad \text { Не была членом СБООН, когда проходило } \\
\text { голосование проекта резолюции СБООН (4 }\end{array}$ \\
\hline
\end{tabular}

41 United Nations Press Release, "Security Council Debates Situation in Syria," 31 January 2012; доступно на www.un.org/apps/news/story.asp? NewsID=41090\&Cr=Syria\&Cr1=.

42 UN Security Council Draft Resolution, 4 October 2011 (minutes of the $6627^{\text {th }}$ meeting of the UNSC); доступно на http://daccess-dds-ny.un.org/doc/UNDOC/PRO/N11/529/74/PDF/N11 52974.pdf?OpenElement. 


\begin{tabular}{|c|c|}
\hline & $\begin{array}{l}\text { февраля 2012), но работала на многосторонней } \\
\text { основе вне СБ вместе с Южной Африкой и Ин- } \\
\text { дией с целью оказания давления на сирийское } \\
\text { правительство начать реформы. }\end{array}$ \\
\hline \multicolumn{2}{|l|}{ Политически актор-Германия } \\
\hline $\begin{array}{l}\text { - Воздержалась при голосовании резо- } \\
\text { люции UNSCR } 1973 \text { (17 марта 2011), } \\
\text { предлагая разрешение Ливийского кри- } \\
\text { зиса политическим, а не военным нажи- } \\
\text { мом. }{ }^{33} \text { Это было отступлением от линии } \\
\text { EC на оказывание давления на прави- } \\
\text { тельство Ливии. }\end{array}$ & $\begin{array}{l}\text { • } \quad \text { Проголосовала в поддержку первого про- } \\
\text { екта резолюции СБООН по Сирии (4 октября } \\
2011) \text { вместе с членами ЕС - Францией, Порту- } \\
\text { галией и Объединенным Королевством. }{ }^{43} \\
\text { • } \quad \text { Проголосовала в поддержку второго про- } \\
\text { екта резолюции СБООН по Сирии (4 февраля } \\
2012) \text { вместе с членами ЕС - Францией, Порту- } \\
\text { галией и Объединенным Королевством. }\end{array}$ \\
\hline \multicolumn{2}{|l|}{ Политический актор - Турция } \\
\hline $\begin{array}{l}\text { • } \quad \text { Турция в целом поддерживала мис- } \\
\text { сии НАТО, позиции СБООН и ЛАГ. } \\
\text { • } \quad \text { Турция оказала денежную помощь } \\
\text { переходному правительству. }{ }^{43}\end{array}$ & $\begin{array}{l}\text { - } \quad \text { Турция работала совместно с ЛАГ для при- } \\
\text { менения санкций к Сирии. } \\
\text { • } \quad \text { Турция, однако, является вторым по значи- } \\
\text { мости торговым партнером Сирии и связана с } \\
\text { Сирией экономическими узами. Турции нужен } \\
\text { сбалансированный подход, чтобы проводить } \\
\text { свою линию внешней политики «никаких про- } \\
\text { блем с соседями». }\end{array}$ \\
\hline
\end{tabular}

\section{Анализ}

Хотя задуманная первоначально как справочное пособие, вышеуказанная таблица дает возможность более глубоко разобраться в некоторых аспектах Ливийского и Сирийского кризисов. Два взаимосвязанных аспекта особенно хорошо иллюстрируют определяющую глобальную тенденцию: намечающийся с 2001 по 2012 спад в политической воле Соединенных Штатов, Объединенного Королевства и Франции следовать концепции «Ответственности защищать» (O3); и второе, реципрочный рост желания Российской Федерации и Китая защищать находящиеся у власти правительства от внешней интервенции.

Что касается первой тенденции, сравнивая участие ЛАГ в разрешении кризисов в Ливии и Сирии, видна уменьшающаяся степень реальных усилий со стороны трех Западных постоянных членов Совета Безопасности ООН применять О3 и стремиться к смене режима. В случае с Ливией, Сенат США активно призывал к интервенции, косвенно используя О3 как мотив. Подобным образом Парламент Объединенного Королевства с нетерпением одобрил финансирование на устанавливаемую военными средствами зоны, запретной для полетов. Франция поспешила признать

43 "Libya: Turkey Recognises Transitional National Council," BBC News Africa (3 July 2011); доступно на www.bbc.co.uk/news/world-africa-14009206.

44 Dan Bilefsky, "Turkey Moves to Intensify Sanctions Against Syria," The New York Times (30 November 2011); доступно на http://www.nytimes.com/2011/12/01/world/middleeast/turkeyintensifies-sanctions-against-syrian-regime.html?ref=arableague. 
ПНС в качестве законного правительства Ливии. Все эти три государства начали военные миссии для того, чтобы установить запретную для полетов зону над Ливией всего в течении двух дней после того, как СБООН потребовал такое действие (показав почти мгновенную реакцию по сравнению с той скоростью ползущего ледника, с которой действуют большинство международных организаций). В случае же с Сирией, наоборот, эта скорая готовность вмешаться оказывается в значительной степени приглушенной. Тогда как в СБООН наблюдались активные дипломатические усилия, их представители быстро шли на компромисс и разбавление формулировок предлагаемых резолюций. В результате проекты резолюций от октября 2011 и февраля 2012 были гораздо менее агрессивны в формулировках по сравнению с резолюциями СБООН по Ливии в 2011. Не было также официальных требований правительств предпринимать соответствующие действия, что имело место в сенате США в 2011. И не было никакой военной мобилизации или серьезных предложений установить запретную для полетов зону.

Другая, противоположная, тенденция наблюдается в отношении двух других постоянных членов Совета Безопасности, России и Китая, при сравнении случаев Ливии в 2011 и Сирии в 2012. Наиболее очевидным отличием в подходах этих двух государств к Сирии и Ливии является решение Китая и России наложить вето на проекты резолюций по Сирии от 4 октября 2011 и 4 февраля 2012, а не воздержаться (как это было в случае резолюции по Ливии UNSCR 1973). Москва и Пекин совершенно очевидно придают большее значение защите режима в Сирии, чем это было сделано в отношении ливийского правительства.

\section{Ограничения}

Сделанные выше выводы, однако, являются неполными и иллюстрируют ограниченные возможности таблицы в анализе меняющихся политических тенденций. Таблица служит для установления того, какие различия существуют между этими двумя случаями, но не углубляется в вопрос почему эти различия существуют. Без вопроса «почему» и без более широкой базы данных, кроме этих двух показательных примеров, не ясно, являются ли эти отличия фундаментальными изменениями политики, или они являются проявлениями одной и той же последовательной политики, примененной в разных формах к конкретным обстоятельствам в Ливии и Сирии. В следующем параграфе будет сделана попытка гипотетически ответить на два связанных вопроса: «почему?» и «что из этого следует?». Однако, для получения конкретных ответов понадобятся дальнейшие исследования.

\section{Дальнейшая оценка}

Существует несколько подспудных сил, которые могли бы объяснить «почему» в отношении обеих вышеупомянутых тенденций. Что касается отличающихся подходов США, Франции и Объединенного Королевства, сдвиг, похоже, обусловлен тремя доминантными ограничениями: внутренней политикой, экономикой и международной правовой средой. И в США, и во Франции в 2012 году будут выборы президента. Имея ввиду вероятность не быть выбранными на следующий срок, со- 
ответствующие находящиеся теперь у власти кандидаты, похоже, в меньшей степени склонны к возможности принятия риска большой иностранной интервенции. Вторая сила, экономика, включает тот факт, что США, Объединенное Королевство и Франция чувствуют бремя глобального финансового кризиса. При внутреннем требовании правительств увеличивать расходы на социальные программы и недавно объявленное сокращение военных расходов, сейчас трудно оправдать слишком высокую цену иностранной интервенции. Следовательно, имея ввиду текущую ситуацию в США, Объединенном Королевстве и Франции, можно сделать вывод, что достаточного политического или денежного капитала на финансирование интервенции больше в наличности нет. Третье, этот дефицит ресурсов дополняется тем фактом, что пока нет никакого международного юридического одобрения интервенции в Сирии - в отличии от случая с Ливией, когда международное сообщество предоставило явное и прямое разрешение на военные действия в виде резолюции СБООН, резолюции, связанной с Ливией организацией, ЛАГ, и последовательные заявления разных государств, что режим Каддафи потерял свою легитимность как суверенное правительство Ливии. Такая правовая платформа, оправдывающая соответствующие действия, отсутствует в случае с Сирией. ЛАГ все еще считает правительство Ассада законным, хотя и совершающим большие ошибки. СБООН все еще не обеспечило одобрение, необходимое для начатия О3 операций.

Изменения в политике России и Китая, возможно, определяются несколькими движущими факторами. Во-первых, у России и Китая гораздо более сильные военные и экономические связи с Сирией, чем были с Ливией. Единственная военноморская база России в Средиземном море находится в Тартусе в Сирии. У Москвы так же есть контракты с Дамаском на доставку вооружений и строительство инфраструктуры на сумму в 20 миллиардов долларов США. Китай положил глаз на нефтяные запасы Сирии, и обе страны - Россия из-за ее близости, а Китай из-за его ненасытного голода на энергетические ресурсы, глубоко заинтересованы в обеспечении стабильности в регионе, - интерес, который может быть подорван падением режима Ассада. Далее, оба государства чувствуют необходимость восстановить свою международную репутацию после того как de facto обеспечили разрешение на защиту западных интересов в Ливии силами НАТО. Разрешив Западу поступить с Ливией как ему было угодно, оба государства теперь пытаются доказать то, что у них не меньше влияния, чем у Западных стран, накладывая вето на любую последующую интервенцию на Ближнем Востоке и в Северной Африке. Доказательства существования такого мотива видны в двухсторонних переговорах с Дамаском и в предложении того, чтобы многосторонние переговоры состоялись не в $\mathrm{OOH}$, а в Москве. Это означает, что Россия в самом деле хочет перемен в Сирии, но перемен, срежиссированных Россией, а не принудительно осуществленных Западом или другими субъектами, действующими не в согласии с Москвой, как например ЛАГ. Существует так же скрытное желание Китая показать и доказать миру свою неинтервенционистскую внешнюю политику, после того как он содействовал, или во всяком случае дал молчаливое согласие на смену режима в Ливии. Накладывая вето на любые резолюции Совета Безопасности ООН по Сирии, Россия и Китай 
пытаются отполировать свой международный имидж и утвердить себя как глобальные Великие силы, равные Западу, противодействуя институциям, которые не согласны с Россией и Китаем. Это может означать усиление борьбы за достижение паритета сил по линии разделения Восток-Запад.

Так же важным в нынешней упорной защите Сирии Россией и Китаем является тот факт, что Россия и Китай представляют собой государства, находящиеся в сходной с режимом Ассада ситуацией: все три государства являются примерами централизованных, недемократических правительств с сильными оппозиционными движениями, угрожающими национальному единству. Эта ментальность людей, находящихся «в одной лодке», порождает желание солидарности. По прошествии того года, когда Time Magazine выбрал человеком года «Протестующего», Китай и Россия обеспокоены потенциальным влиянием еще одного успешного переворота на пассивность их населения. Существует озабоченность, что эффект домино, который начался в Тунисе в 2011, может распространиться на Москву и Пекин, если допустить, чтобы он прошел через Дамаск. Россия столкнулась с недавними протестами против подтасовки «манипулированных выборов», так же она чувствует постоянную угрозу со стороны чеченского меньшинства. Подобным образом Китай в марте 2011 пережил Юнанский протест, в апреле 2011 - беспорядки в Шанхае, в июне 2011 - беспорядки в Шеньчжэне, еженедельные продемократические протесты в Пекине и чувствует постоянную угрозу со стороны меньшинств, населяющих Западный Китай. Еще один успешный переворот в Дамаске может поощрить протестующих вне Сирии. Таким образом, обеспечение стабильности иностранного сирийского режима рассматривается Пекином и Москвой как вклад во внутреннюю безопасность Китая и России.

\section{Заключение}

Эта статья имеет целью в основном предоставить подробное сравнение развития международных событий вокруг ситуаций в Ливии в 2011 и Сирии в 2012, таким образом иллюстрируя все более или менее значительные отличия между ними и все изменения в политике соответствующих политических акторов. Однако, утверждения относительно последствий этих отличий, приведенные в предыдущем параграфе, являются только умозрительными построениями, сделанными, чтобы заполнить информационные пробелы в таблице. Необходимы дальнейшие исследования, чтобы ясно понять, что за силы стоят в основе изменений в политике и для того, чтобы предвидеть отзвук этих изменений в будущей внешней политике. 


\section{Литература}

"Libya: France Recognises Rebels as Government." BBC News Europe (2011).

"Libya: Turkey Recognises Transitional National Council." BBC News Africa (2011).

"Syria Unrest: UK, France and Italy Press for Sanctions." BBC World News (2011).

Agreement, Council of the Eur. "Cooperation Agreement between the European Economic Community and the Syrian Arab Republic." Brussels: Official Journal of the European Communities (1977).

Bilefsky, Dan. "Turkey Moves to Intensify Sanctions Against Syria." The New York Times (2011).

Defense, French Ministry o. Libye: point de situation opération Harmattan $n^{\circ} 1 ., 2011$.

Taylor, Claire. In Brief: Parliamentary Approval for Deploying the Armed Forces. House of Commons Standard Note SN/IA/5908 (Lon $\neg$ don: House of Commons Library, 2011.

Zein, H.. "Syria Rejects Decisions of AL Ministerial Meeting as Flagrant Interference in Syria's Affairs \& Encroachment on its National Sovereignty." Sana Syria News Agency (2012). 